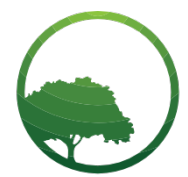

Research in Business \& Social Science

IJRBS VOL 8 NO 5 ISSN: 2147-4478

\title{
Determinants of purchase intention toward halal packaged food from non-muslim manufacturers: A comparative study of Muslim in Thailand and Indonesia
}

\author{
Athapol Ruangkanjanases ${ }^{a *}$, Tassaya Sermsaksopon ${ }^{b}$, Bachtiar H. Simamora $^{c}$ \\ ${ }^{a, b}$ Chulalongkorn Business School, Chulalongkorn University, Thailand \\ ${ }^{c}$ BINUS Business School, Bina Nusantara University, Indonesia
}

\begin{tabular}{l} 
A R T I C L E I N F O \\
\hline Article history: \\
Received 15 July 19 \\
Received in revised form 29 July 19 \\
Accepted 05 August 19 \\
\hline Keywords: \\
Muslim \\
Purchase \\
Halal \\
Packaged-food \\
Thailand \\
Indonesia \\
JEL Classification: \\
O15 \\
P36
\end{tabular}

\begin{abstract}
A B S T R A C T
Food and beverage has become a competitive sector for companies in ASEAN countries to expand strategically in the region and to cash in on the implementation of the ASEAN Economic Community (AEC). Halal packaged food products have attracted much attention in ASEAN where its largest member, Indonesia, is the world's most populous Muslim country and is a major market in the region. For a non-Muslim country like Thailand, Islam also has a significant role in being the second popular religion after Buddhism. Although Islamic population in Thailand is not as great as in Islamic countries, Thailand plays a substantial part in halal business as being recognized as a food production base exporting halal food worldwide. Therefore, the major objective of this study is to identify and analyze the significant factors that influence purchase intention of Thai and Indonesian Muslims toward halal packaged food products from non-Muslim manufacturers. This study used a survey to collect data consisting of 200 Thai respondents and 200 Indonesian respondents. The results indicated that product ingredients significantly influenced consumers' intention to purchase both in Thailand and Indonesia while halal certification only significantly influenced consumers' intention to purchase in Indonesia.
\end{abstract}

\section{Introduction}

For over decades, halal products have attracted much attention among members of Organization of the Islamic Conference (OIC) countries. It has been estimated that the trade value of halal products in the global market has reached more than USD 600 billion and the trade will keep increasing at 20 to 30 percent annually. The total of potential markets for halal products, Indonesia has the highest contribution among all the countries at around 180 million people, with approximately $87.2 \%$ of Indonesia's total population identifying themselves as Muslims. Besides Indonesia, Thailand also has a large number of Muslims. There were roughly 3.5 million Muslims in Thailand in 2015 (Central Intelligence Agency, 2015). Although Islamic population in Thailand is not as great as in those OIC countries, Thailand plays a substantial part in halal business since it is one of the big players in exporting halal products to the world as well as being recognized as a food production base. Therefore, Thailand does not only consume halal products domestically, but also export internationally. However, several articles and studies revealed that there were Muslim consumers who still refused to buy non-Muslims' halal certified packaged food. The core characteristics of halal food associating with the trust and confidence in knowledge and how the product is manufactured are the key criteria that Muslim consumers always take into consideration. As a non-Muslim producer in Thailand, it is critical to figure out whether or not a non-Muslim status is one of the factors demotivating purchase intention of Muslim consumers in such a big Islamic country as Indonesia. Very few studies have been conducted to

* Corresponding author. ORCID ID: 0000-0001-6766-5785

Peer review under responsibility of Bussecon International Academy.

(C) 2019 Bussecon International. Hosting by SSBFNET- Center for Strategic Studies in Business \& Finance. All rights reserved.

https://doi.org/10.20525/ijrbs.v8i5.312 
comprehensively examine this issue. In recent years, the study of Yunus et al. (2014) had discovered consumers' perception in Malaysia and was a main inspiration for this study to conduct a research under the same areas in Thailand and Indonesia.

\section{Literature Review}

The literature review consists of 4 parts which are Halal food markets, Halal packaged food, overview of Muslim in Thailand and Indonesia, and the Factors affecting intention to purchase.

\section{Halal food markets \& packaged foods}

Halal is derived from Arabic meaning "permitted". In regards to Islamic religion, the word itself is used to refer to anything that is permitted or lawful, for example, permitted to eat, to drink, to perform, or to utilize. Halal is often used to refer to foods and drinks that are permissible for Muslims to eat or drink under Islamic Shariyah (law). The global Muslim population is impending 1.6 billion people. Expectedly, Muslims will be accounting for 30\% of the world's population by 2025 . Roughly, there are around 1.3 billion Muslims in the world and 1.5 billion halal consumers (Daganghalal, 2015). Two strong markets for halal products, according to Riaz (1998), are Southeast Asia and the Middle East. Southeast Asia is home to more than 250 million halal consumers. Indonesia, Malaysia, and Singapore have regulations to control the import of halal-certified products for years.

Halal food refers to food that does not contain pork and its by products, alcohol, blood, certain types of animals, or all kinds of meat that has not been slaughtered by the means of Islamic procedure (Hamdan et al., 2013). This positive indication emphasizes a great opportunity in profit-making business by fulfilling demand from Muslim as well as non-Muslim consumers. The rapid growth of halal market is not just restricted to only meat. It covers all sides of food business including packaged food industry. According to the Food Act of Malaysia (1983), "packaged food" refers to "which food is wholly or partly cased, covered, enclosed, contained, placed or otherwise packaged in any way whatsoever and includes any basket, pail, tray or receptacle of any kind whether opened or closed.

\section{An Overview of Muslim in Thailand and Indonesia}

At present, there are approximately $4.9 \%$ of Muslims contributing in almost 68 million people in Thailand. The majority of Muslims people are concentrated in the 3 southern border provinces consisting of Pattani, Yala and Narathiwat.

In Indonesia, Islam is the dominant religion in the country. Indonesia also has a larger Muslim population than any other countries in the world, with approximately 202.9 million identifying themselves as Muslim (Pew Research Center, 2009). The large number implies that approximately $13 \%$ of the total number of Muslims in the world live in Indonesia.

\section{Factors affecting intention to purchase}

In reference with the study of Wilson et al. (2011), it was revealed that Halal-conscious consumers are risk averse, which drives discerning and high-involvement behavioral traits. On the other hand, Aziz et al. (2013) found that halal awareness, halal certification, marketing promotion, and brand were positively related to purchase intention, whereas food quality was negatively associated with it. Their findings also indicated a positive relationship between halal certification and intention to purchase.

This study was mainly adopted from previous studies such as the study of Yunus et al. (2014), where 3 independent variables - halal awareness, Islamic brand and product ingredients, were applied to evaluate Muslim's purchase intention toward non-Muslim's halal packaged food manufacturers. The findings from another study also supports a positive relationship between halal awareness and purchase intention (Aziz Y. \& Chok N., 2013), but the survey was only conducted in Malaysia. Therefore, this study attempted to discover more about Indonesian and Thai Muslim consumers as well as to provide comparative information in regards to underlying factors that influence Muslim's purchase intention in these 2 countries. Additionally, another important variable potentially having the impact on purchase intention, namely halal certification, was included in this study since halal certification from an authorized body is important to verify that the processed food products are genuinely halal (Hamdan, 2013).

\section{Hypotheses development and research model}

The conceptual model consists of 3 independent variables which are Halal certification, Islamic Brand, and Product Ingrediants. The detail is provided as follows;

\section{Halal certification}

Halal certification refers to the official recognition of the orderly process of preparation, slaughtering, cleaning, handling, and other relevant management practices by the established body (Aziz \& Chok, 2013) such as MUI in Indonesia and CICOT in Thailand. Although certified halal food is a requirement for Muslims, the perception of halal food in the aspect of halal certification by the nonMuslims is determined by a positive personal attitude, which may eventually influence their intention to purchase halal food. The findings of Aziz \& Chok (2013) proved that halal certification had a signification positive relationship with non-Muslim consumers' intention to purchase halal products. It also implied that halal certification provided recognition and quality assurance to non-Muslim consumers when they displayed their willingness to purchase in the future. Therefore, this study hypothesizes that: 
H1a: Halal certification has a significant impact on Thai Muslims' intention to purchase a non-Muslim's halal packaged food.

H1b: Halal certification has a significant impact on Indonesian Muslims' intention to purchase a non-Muslim's halal packaged food.

\section{Islamic brand}

Alserhan (2010) described that Islamic brands can be categorized in 4 groups - True Islamic Brands (produced in Islamic country and targeted at Muslims), Traditional Islamic Brands (originated from Islamic country and targeted at Muslims), Inbound Islamic Brands (originated from Islamic country and not necessarily targeted at Muslims) and lastly, Outbound Islamic Brands (originated from non-Islamic country and not necessarily targeted at Muslims). The results of this classification indicated different attitudes, subjective norms, intentions and purchase behavior. Therefore, according to the objectives of this study, halal packaged food produced by non-Muslim manufacturers in Indonesia can be considered as Inbound Islamic Brand. On the other hand, halal packaged food produced by non-Muslim manufacturers in Thailand can be considered as Outbound Islamic Brands (Halim \& Salleh, 2012). Thus, this study hypothesizes that:

H2a: Islamic brand has a significant impact on Thai Muslims' intention to purchase a non-Muslim's halal packaged food.

H2b: Islamic brand has a significant impact on Indonesian Muslims' intention to purchase a non-Muslim's halal packaged food.

\section{Product ingredients}

Consumers' purchase intentions toward food were highly associated with individual and environmental factors which also included product ingredients (Golnaz et al. 2009). This is because information, knowledge and Shariyah play such important roles for Muslims in making their food choices. In Islamic perspective, product ingredients may cover some issues that must be taken into consideration and it also includes the issues of consumer's familiarity on the ingredients and quality as well as safety of the food contents.

According to the previous study of Yunus et al. (2014), majority of the respondents agreed that information about the product ingredients on the label of packaged food was very important to them. As a result, the measure was also applied with this study to discover more about the relationship between product ingredients and purchase intention of the Muslim consumers from Thailand and Indonesia. Therefore, this study hypothesizes that:

H3a. Product ingredients have a significant impact on Thai Muslims' intention to purchase a non-Muslim's halal packaged food.

H3b. Product ingredients have a significant impact on Indonesian Muslims' intention to purchase a non-Muslim's halal packaged food.

The conceptual model of this research is shown in Fig 1.

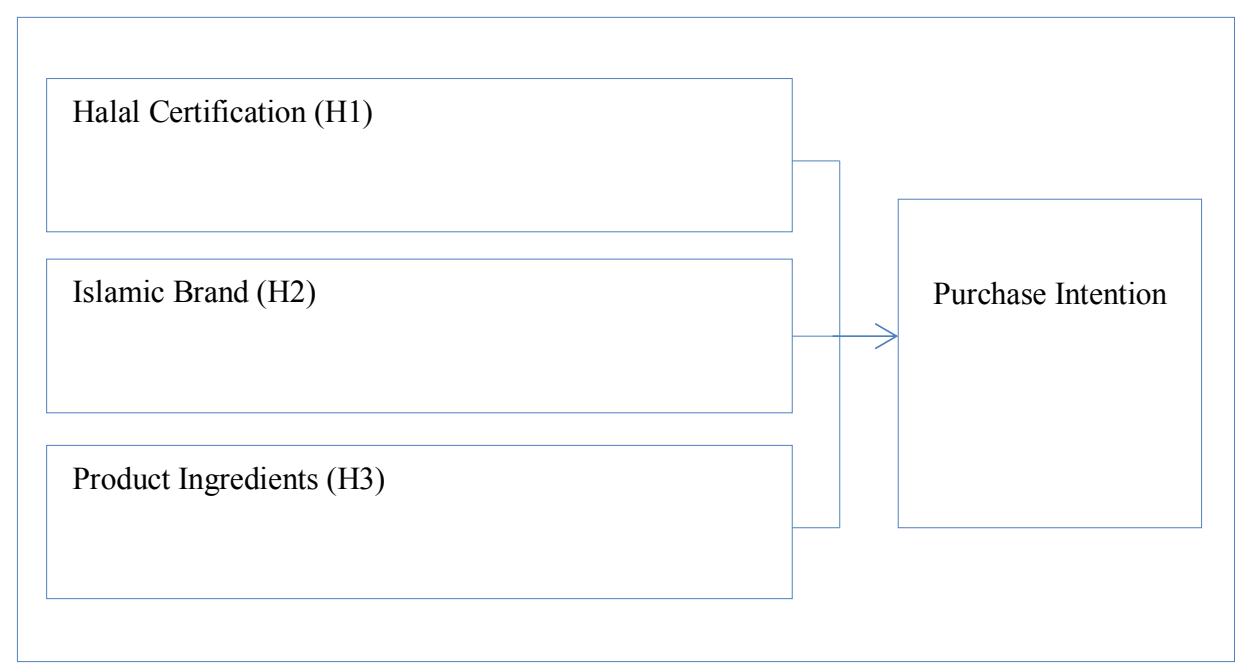

Figure 1: Conceptual Model 


\section{Research Methodology}

\section{Samples and data collection}

The target populations of this study are both Thai and Indonesian Muslims. In accordance with the data in 2015 from Central Intelligence Agency (2015), there were 3,330,843 Muslim people in Thailand while Indonesia had 223,226,483 Muslim people respectively. The combined Muslim population of both countries was 226,557,362. By using 95 percent confidence level with sampling error of 5 percent according to Yamane (1967), appropriate sample size of respondents calculated was 400. The researchers used the quota sampling technique for data collection; half of samples were Thais (200) and the rest of samples were Indonesians (200). An online survey questionnaire was developed to test hypotheses in this research. The survey questionnaire was pretested with 30 Thai Muslims and 30 Indonesian Muslims. Questionnaires were distributed from October 2015 to March 2016. Total of 400 completed questionnaires, 200 from Thai Muslims and 200 from Indonesian Muslims, were collected.

\section{Research instrument and variable measurement}

Eleven questions were used to measure the 3 independent variables and 3 questions were used to measure one dependent variable. Besides demographic profiles, all items were measured based upon a five-point Likert Scale ranging from 1 (strongly disagree) to 5 (strongly agree). A sample of questionnaire is in the Appendix.

\section{Reliability}

The reliability of the questionnaire was tested by using Cronbach's alpha. Table 1 showed that the reliability coefficients $(\alpha)$ of all independent variables were above 0.70 . Therefore, the items used to measure the constructs were reliable [14].

Table 1: Reliability analysis

\begin{tabular}{llc}
\hline Variables & $\begin{array}{l}\text { Cronbach's alpha } \\
\text { (Thailand) }\end{array}$ & $\begin{array}{l}\text { Cronbach's alpha } \\
\text { (Indonesia) }\end{array}$ \\
\hline Halal certification & 0.766 & 0.815 \\
\hline Islamic brand & 0.715 & 0.781 \\
\hline Product Ingredients & 0.787 & 0.736
\end{tabular}

Source: Authors' study

\section{Validity}

Factor analysis with varimax rotation was applied to test the validity of the constructs. Factor loading of 0.50 is used as a cut-off point as suggested by Hair et al. (2006). The results in Table 2 confirmed the existence of 3 factors with eigenvalues greater than 1.0 and all items had a factor loading of more than 0.50 . These results confirmed that each of these constructs was unidimensional and factorially distinct, and that all items used to operationalize the particular construct were loaded onto a single factor (Teo, 2001).

Table 2: Factor analysis

\begin{tabular}{llccc}
\hline Construct & No. of Items & Factor Loading & Eigenvalues & Percentage of Variance \\
\hline Halal Certification & 3 & $0.545-0.882$ & 3.102 & 28.198 \\
\hline Islamic brand & 4 & $0.606-0.829$ & 2.374 & 21.583 \\
\hline Product Ingredients & 4 & $0.620-0.847$ & 2.236 & 20.330
\end{tabular}

Source: Authors' study 


\section{Result and Discussion}

Statistical Package for Social Science (SPSS) is used to analyze primary data from questionnaires.

\section{Descriptive statistics}

Descriptive statistics of samples on demographic data are shown in Table 3. More than 90 percent of respondents had experiences in purchasing halal packaged food from non-Muslim manufacturers. For level of religiosity, most respondents in both Thailand and Indonesia declared themselves as fairly devout.

Table 3: Demographic profile

\begin{tabular}{|c|c|c|c|c|}
\hline \multirow[t]{2}{*}{ Demographic profile } & \multicolumn{2}{|c|}{ Thailand } & \multicolumn{2}{|l|}{ Indonesia } \\
\hline & $\mathbf{N}$ & $\%$ & $\mathbf{N}$ & $\%$ \\
\hline \multicolumn{5}{|l|}{ Gender } \\
\hline Female & 133 & 66.5 & 95 & 47.6 \\
\hline Male & 67 & 33.5 & 105 & 52.4 \\
\hline \multicolumn{5}{|l|}{ Age } \\
\hline$<15$ & 1 & 0.5 & 0 & 0.0 \\
\hline $15-34$ & 155 & 78 & 141 & 70.6 \\
\hline $35-54$ & 39 & 20 & 56 & 27.8 \\
\hline $55-49$ & 5 & 2.5 & 3 & 1.6 \\
\hline \multicolumn{5}{|l|}{ Education level } \\
\hline High school or lower & 17 & 8.5 & 25 & 12.5 \\
\hline Diploma & 10 & 5 & 46 & 23.0 \\
\hline Bachelor's degree & 147 & 73.5 & 77 & 38.5 \\
\hline Master degree & 24 & 12 & 46 & 23.0 \\
\hline Doctoral degree & 2 & 1 & 6 & 3.0 \\
\hline \multicolumn{5}{|l|}{ Level of religiousity } \\
\hline Not devout & 21 & 10.5 & 5 & 2.4 \\
\hline Fairly devout & 151 & 75.5 & 100 & 50.0 \\
\hline Extremely devout & 28 & 14 & 95 & 47.6 \\
\hline \multicolumn{5}{|c|}{$\begin{array}{l}\text { Experiences in Purchasing halal packaged } \\
\text { food from non-Muslim manufacturers }\end{array}$} \\
\hline Yes & 187 & 93.5 & 181 & 90.5 \\
\hline No & 13 & 6.5 & 19 & 9.5 \\
\hline
\end{tabular}

Source: Authors' study

\section{Correlation Analysis}

The correlation of means of the variables was conducted to determine variability of the factors as shown in Table 4 and Table 5 . All correlations between independent variables were below 0.7 . There was no variable that was interpreted as strong linear correlation for both respondent groups in the study. The results in Table 4 indicated that the factor that had the strongest relationship for Thai Muslims' intention to purchase was product ingredients $(\mathrm{r}=0.368)$. Meanwhile, the factor that had the strongest relationship for Indonesian Muslims' intention to purchase was also product ingredients $(r=0.496)$, followed by halal certification $(r=0.477)$ as shown in Table 5.

Table 4: Correlation analysis for Thailand

\begin{tabular}{lllll}
\hline Variables & HC & IB & Pro I & Pur I \\
\hline Halal certification & 1 & 0.524 & 0.527 & 0.293 \\
\hline Islamic brand & & 1 & 0.473 & 0.274 \\
\hline Product ingredients & & 1 & 0.368 \\
\hline Purchase intention & & & 1 \\
\hline
\end{tabular}

Source: Authors' study 
Table 5: Correlation analysis for Indonesia

\begin{tabular}{lllll}
\hline Variables & HC & IB & Pro I & Pur I \\
\hline Halal certification & 1 & 0.611 & 0.689 & 0.477 \\
\hline Islamic brand & & 1 & 0.556 & 0.365 \\
\hline Product ingredients & & 1 & 0.496 \\
\hline Purchase intention & & & 1 \\
\hline
\end{tabular}

Source: Authors'study

\section{Collinearity diagnostics tests}

The collinearity diagnostics tests were performed to validate the variables and detect any multicollinearity problem. According to O'Brien (2007), a variable that has a lesser tolerance value of 0.20 or a VIF greater than 5 possess a threat of having multicollinearity. The results of collinearity diagnostics test were displayed in Table 6 and Table 7 . The results showed that there were no variables possessing a threat of multicollinearity, thus, validate the variables for both samples.

Table 6: Collinearity statistics of Thailand

\begin{tabular}{lll}
\hline Variables & \multicolumn{1}{c}{ Collinearity Statistics } & \\
\hline & Tolerance & VIF \\
\hline Halal certification & 0.625 & 1.600 \\
\hline Islamic brand & 0.672 & 1.489 \\
\hline Product ingredients & 0.669 & 1.495
\end{tabular}

Source: Authors' study

Table 7: Collinearity statistics of Indonesia

\begin{tabular}{lll}
\hline Variables & \multicolumn{1}{c}{ Collinearity Statistics } \\
\hline & Tolerance & VIF \\
\hline Halal certification & 0.424 & 2.360 \\
\hline Islamic brand & 0.597 & 1.674 \\
\hline Product ingredients & 0.467 & 2.143 \\
\hline
\end{tabular}

Source: Authors' study

\section{Stepwise multiple regression}

According to Table 8, one variable having a significant impact to purchase intention of Thai Muslim respondents was product ingredients $(\beta=0.368, p=0.001)$. The adjusted $R^{2}$ was at 0.131 , which means that the predictor could explain $13.1 \%$ of the variance of the dependent variable (purchase intention).

Table 9 indicated that two variables having a significant impact to purchase intention of Indonesian Muslim respondents were product ingredients $(\beta=0.318, \mathrm{p}=0.004)$ and halal certification $(\beta=0.250, \mathrm{p}=0.024)$. The adjusted $\mathrm{R}^{2}$ was at 0.265 , which means that the two predictors could explain $26.5 \%$ of the variance of the dependent variable (purchase intention).

The results from the multiple regression analysis showed that the hypotheses H1b, H3a and H3b were supported. The results of the multiple regression did not support $\mathrm{H} 1 \mathrm{a}, \mathrm{H} 2 \mathrm{a}$ and $\mathrm{H} 2 \mathrm{~b}$.

In conclusion, factor influencing Thai Muslims' intention to purchase non-Muslim's halal packaged food is shown in Figure 2 and factors influencing Indonesian Muslims' intention to purchase non-Muslim's halal packaged food is shown in Figure 3.

Table 8: Stepwise multiple regression for Thailand

\begin{tabular}{llllllllll}
\hline & Variables & B & $\boldsymbol{\beta}$ & $\mathbf{t}$ & Sig. & $\mathbf{R}$ & $\mathbf{R}^{\mathbf{2}}$ & Adj. R & Overall F $^{\mathbf{2}}$ \\
\hline Criterion: & Purchase intention & & & & & 0.368 & 0.136 & 0.131 & 31.051 \\
\hline Predictor: & $\begin{array}{l}\text { Product } \\
\text { ingredients }\end{array}$ & 0.388 & 0.368 & 5.572 & 0.001 & & & & \\
\hline
\end{tabular}

Source: Authors' study 
Table 9: Stepwise multiple regression for Indonesia

\begin{tabular}{llllllllll}
\hline & Variables & B & $\boldsymbol{\beta}$ & $\mathbf{t}$ & Sig. & $\mathbf{R}$ & $\mathbf{R}^{\mathbf{2}}$ & Adj. R$^{\mathbf{2}}$ & Overall F \\
\hline Criterion: & Purchase intention & & & & & 0.526 & 0.277 & 0.265 & 23.541 \\
\hline Predictor: & $\begin{array}{l}\text { Product } \\
\text { ingredients }\end{array}$ & 0.267 & 0.318 & 2.898 & 0.004 & & & & \\
& $\begin{array}{l}\text { Halal } \\
\text { certification }\end{array}$ & 0.162 & 0.250 & 2.282 & 0.024 & & & & \\
& & & & & & & & \\
\hline
\end{tabular}

Source: Authors' study

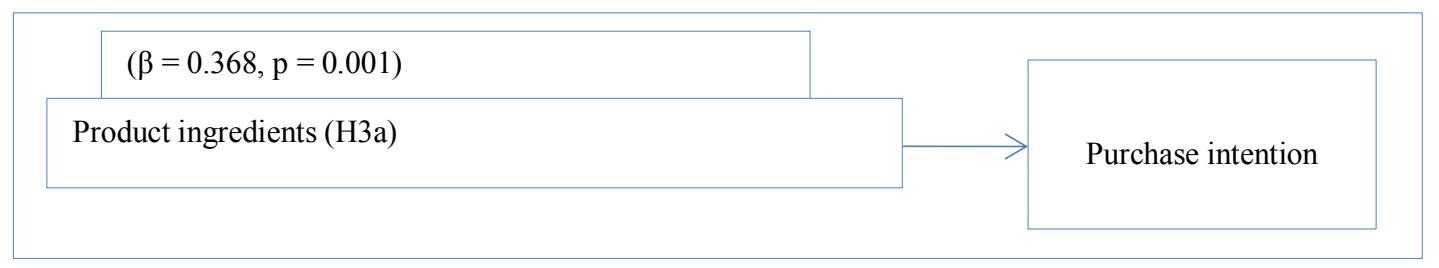

Figure 2: Factor influencing Thai Muslims' intention to purchase non-Muslim's halal packaged food

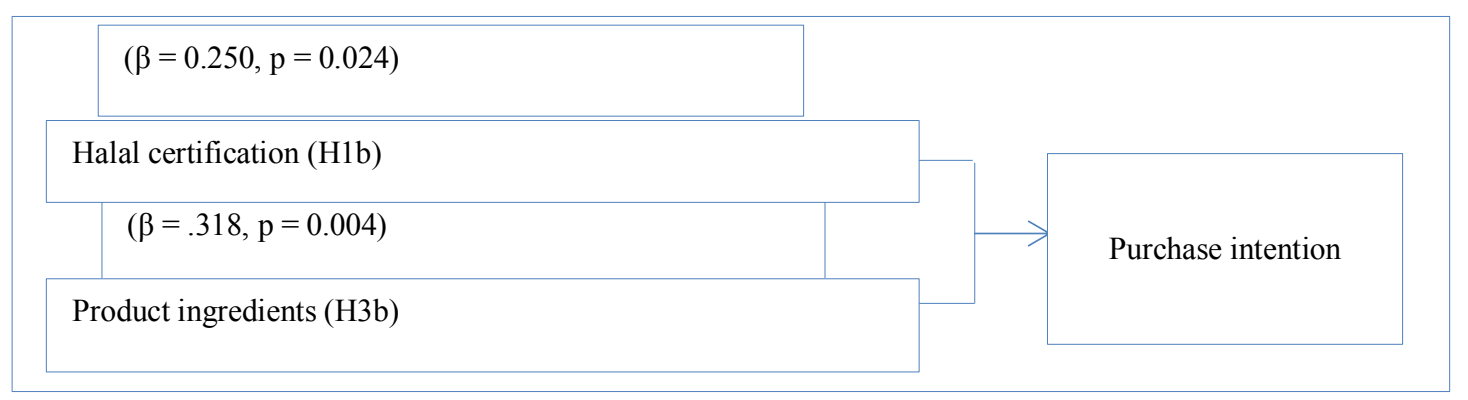

Figure 3: Factor influencing Indonesian Muslims' intention to purchase non-Muslim's halal packaged food

\section{Conclusions}

The results of this study indicate that product ingredients were the significant predictor that impacted the intention to purchase of both Thai and Indonesian Muslims. These results were also consistent with the study conducted by Golnaz et al. (2012), whose study explained that no clear list of ingredients made consumers feel less confident with the products. Moreover, the findings from this study also aligned with the findings from the study of Yunus et al. (2014), which was tested the Muslim respondents from Klang Valley, Malaysia. This study also demonstrated that halal certification had a significant positive relationship with Indonesian Muslims' intention to purchase non-Muslim's halal packaged food. Although the two variables were verified to be significant factors influencing consumers' purchase intention in this study (product ingredients for Thai Muslims and product ingredients along with halal certification for Indonesian Muslims), the predicting percentages (adjusted $\mathrm{R}^{2}$ ) were substantially low. It is very likely that there may be some other factors that significantly impact intention to purchase. Unfortunately, such factors were not included as independent variables in this study and they hold much higher degree of prediction. The missing potential factors that Thai and Indonesian Muslims consider when making their purchase could possibly be price, taste, marketing promotion, discounts and perceived quality since these factors showed positive impact toward purchase intention of consumers in former studies. In reference with the study of Ahmad et al. (2013), price and taste were tested to be significant factors. Marketing promotion was proven to be significant in the study of Aziz et al. (2012). Finally, price discounts and perceived quality were significant in the study of Grewal et al. (1995) as well.

Despite insignificant relationship toward purchase intention of Thai Muslim consumers in this study, halal certification actually plays such an important role that it is the first criterion Muslims consider when purchasing products, specifically in food category. This is because halal certification from an authorized body is important to verify that the processed food products are genuinely halal (Hamdan, 2013). Having a certified halal label would be an advantage in order to attract more Muslim consumers. And although halal certification is an option for food manufacturers, they should consider applying for halal certification if they aim to capture the market globally. Moreover, the certify bodies in every country should elevate the standard to always stay competitive. In conclusion, the study has distinguished the significant factors that could affect Thai and Indonesian Muslims toward non-Muslim's halal packaged 
food products. The results of this study can be used as guidance to propose development in attracting Muslim consumers as well as expanding to a Muslim market. Future studies using the same conceptual model in other countries are also recommended.

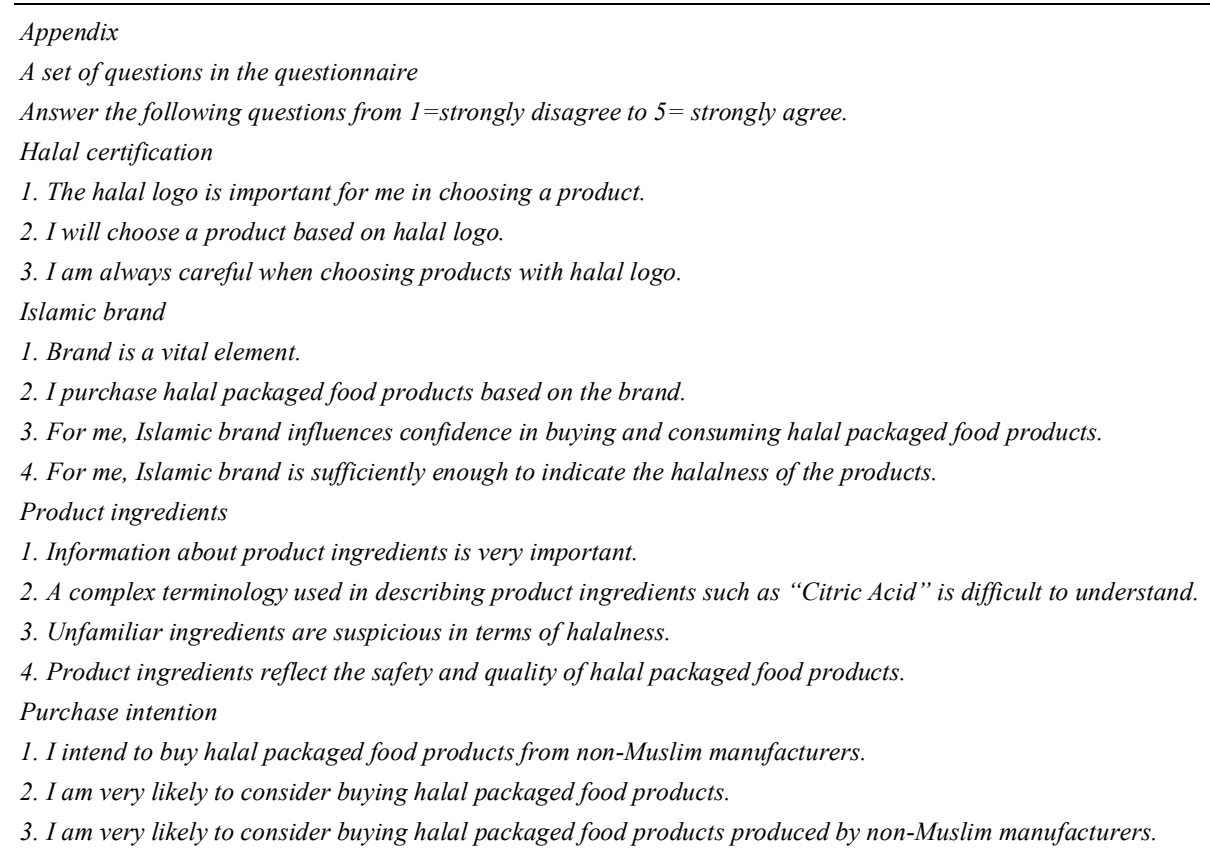

\section{References}

Act 281 (1983). Food Act of Malaysia 1983, Laws of Malaysia, Percetakan Nasional Malaysia Berhad.

Ahmad, N., Abaidah, T. \& Yahya, M. (2013). A Study on Halal Food Awareness among Muslim Customers in Klang Valley, Proceeding of 4th International Conference on Business and Economic Research.

Alserhan, B.A. (2010). Islamic branding: A Conceptualization of Related Terms. Brand Management, 18(1), 34-49.

Aziz A., Y. \& Chok, N. V. (2013). The Role of Halal Awareness, Halal Certification, and Marketing Components in Determining Halal Purchase Intention among Non-Muslims in Malaysia: A Structural Equation Modeling Approach. Journal of International Food \& Agribusiness Marketing, 25(1), 1-23. . https://dx.doi.org/10.1080/08974438.2013.723997

Aziz A., Y. \& Vui C.N. (2012). The Role of Halal Awareness and Halal Certification in Influencing Non-Muslims' Purchase Intention, Proceeding of 3rd International Conference on Business and Economic Research, Bandung, Indonesia, 1819-1830.

Central Intelligence Agency. (2015).The World Factbook. Retrieved from https://www.cia.gov/library/ publications/the-worldfactbook/geos/th.html.

Daganghalal. (2015). World of Halal. Retrieved from http://www.daganghalal.com/HalalInfo/WorldOf Halal.aspx.

Golnaz, R., Zainalabidin, M. \& Mad Nasir, S. (2012). Assessment of Consumers' Confidence on Halal Labelled Manufactured Food in Malaysia. Pertanika Journal of Social Science \& Humanities. 20 (1): 33 - 42.

Golnaz, R., Zainal, A.M., Shamsudin, M.N. \& Chiew, E. (2009). Concern for

Halalness of Halal-Labelled Food Products among Muslim Consumers in Malaysia: Evaluation of Selected Demographic Factors. Economic and Technology Management Review, 4, 65-73.

Grewal, D., Krishnan, R., Baker, J. \& Borin, N. (1995). The Effect of Store Name, Brand Name and Price Discounts on Consumers' Evaluations and Purchase Intentions. Retrieved from http://digitalcommons.calpoly.edu/cgi/ viewcontent.cgi? article $=1010 \&$ context $=$ mkt_fac.

Hair, J., Black, W., Babin, B., Anderson, R., Tatham, R. (2006). Multivariate Data Analysis. Upper Saddle River, NJ: Prentice Hall. Halim, M.A. \& Salleh, M.M. (2012). The Possibility of Uniformity on Halal Standards in Organization of Islamic Countries (OIC), World Applied Sciences Journal, 17, 06-10.

Hamdan, H., Issa, Z.M., Abu, N., \& Jusoff, K. (2013). Purchasing Decisions among Muslim Consumers of Processed Halal Food Products. Journal of Food Products Marketing, 19, 54-61.

O’Brien, R. (2007). A Caution Regarding Rules of Thumb for Variance Inflation Factors. Quality \& Quantity, 41 (5), 673-690.

Pew Research Center. (October 2009). Mapping the Global Muslim Population. Retrieved from http://pewforum.org/newassets/images/reports/ Muslimpopulation /Muslimpopulation.pdf [October 20, 2015].

Riaz, M.N. (1998). Halal Food: An Insight into a Growing Food Industry Segment. Food Marketing and Technology, $12(6), 6-9$.

Teo, T.S.H. (2001). Demographic and motivation variables associated with Internet usage activities. Internet Research, 11, 125-137. 
Wilson, J., \& Liu J. (2011). The challenges of Islamic branding: navigating emotions and halal. Journal of Islamic Marketing. 2(1), $28-42$.

Yamane, T. (1967). Statistics: An Introductory Analysis, 2nd Ed., New York: Harper and Row.

Yunus, N., Rashid, W., Ariffin, N., \& Rashid, N. (2014). Muslim's Purchase Intention towards Non-Muslim's Halal Packaged Food Manufacturer. Procedia - Social and Behavioral Sciences. 130,145-154. https://dx.doi.org/10.1016/j.sbspro.2014.04.018 